DOI https://doi.org/10.30525/978-9934-26-039-1-85

\title{
РЕЛІГІЙНІ СИМВОЛИ В МОВІ ЦЕРКОВНО-КОНФЕСІЙНИХ ЗМІ УКРАЇНИ: ІНВАРІАНТИ ІНТЕРПРЕТАЦІЇ ТА ТАКСОНІМІЗАЦЇ̈
}

\author{
Сазонова Ю. О. \\ кандидат наук із сочіальних комунікацій, \\ доиент кафедри журналістики \\ Навчально-наукового иентру «Школа журналістики» \\ Чорноморського національного університету імені Петра Могили \\ м. Миколаїв, Украӥна
}

На початку 90-х р. в Україні відбувається активний розвиток церковно-конфесійних ЗМІ, що пов'язано з розпадом СРСР, де церковна преса перебувала в стагнації, оскільки радянською владою насаджувався атеїзм. Після здобуття Україною незалежності виникають ЗМІ різних конфесій: православні («Український православний вісник» (1990), «Кирилиця» (1998), «Донбасс православный»« (1997), «Мир», «Живой родник» (1997), «Спасите наши души!» та ін.), протестантські та неопротестанські («Вісник миру», (1999), «Адвентистський вісник» (2000), «Вічний скарб» (2003), та ін.), католицькі («Парафіяльна газета»), ісламські («Мінарет»), церковні часописи для молоді («Церква і молодь», «Мета», «Отрок» та ін.) та дитячі релігійні видання («Радость моя», «Шишкин лес» та ін.). Але незважаючи на швидке поширення церковноконфесійних ЗМІ в інформаційному просторі України, релігійна преса залишається малодослідженим сегментом вітчизняної журналістики, насамперед в лінгвістичному аспекті (на рівні семіотики, прагматики, семасіології, дискурсології, практичної й функціональної стилістики).

Релігійна журналістика концептуалізує конфесійний стиль, що характеризується частотним використанням символічних стилісистем (слів-символів, архетипів та зображальних символів) та $є$ одним 3 найменш досліджених функціональних стилів мовлення. Преса різних церковних конфесій (православна, католицька, протестантська та ісламська) характеризується функціонуванням абсолютно гетерогенних дискурсів образів-символів. Отже, аспекти прагматики, інтерпретації та типологізації символічних стилісистем в мові православних мас-медіа $\epsilon$ одним 3 найменш вивчених пластів української та світової медіалінгвістики. Усе вищезазначене й зумовлює актуальність нашої роботи. 
Мета дослідження - розкрити особливості функціонального стилю в мові релігійної (православної та протестанської) преси Східної та Центральної України, здійснити таксонімізацію релігійних символів та окреслити інваріанти їх інтерпретації.

Ця тема висвітлювалася в працях Б. Білецької [1], де розкриваються сутнісні ознаки символу як релігійного феномену в контексті релігієзнавчого дискурсу; М. Єреська [2], у якій аналізується генеза релігійних символів та їх еволюція, визначено основні функції релігійних символів; Н. Кочан [3; 4], де тлумачаться та параметризуються певні символи християнської православної церкви; Л. Павлюк [5], у якій розглянуто використання релігійних символів у різних типах ЗМІ та запропоновано їх інтерпретацію; а також в проведеному нами дослідженні [6], де визначено стан, функції та перспективи розвитку релігійної преси Донбасу та здійснено лінгвістичний аналіз релігійних текстів.

Медіатизація релігійного дискурсу, що активно виявляється в останні 20-річчя на українському медіа-ринку, концептуалізує вживання в мові ЗМІ відносно нового функціонального стилю мовлення - конфесійного або сакрального. Конституційною ознакою конфесійного стилю $є$ релігійний символ. За М. Єресько, «релігійний символ репрезентує поняття про надприродне на рівні свідомості у формі фантастичних образів чи матеріальних об'єктів, наділених містичними властивостями» [2, с. 9]. Релігійні символи становлять важливий елемент релігійного культу. Символи засадничо інтегрують, окрім прямого значення, також компліментарні - містичне (езотеричне) чи магічне (трансцендентне) значення. Релігійним символом стає конкретне явище, що підлягає верифікації, якому віра надає надприродного значення.

На основі проаналізованих нами мас-медіа можемо запропонувати розгорнуту таксонімізацію релігійних символів, що функціонують у церковній пресі Україні: символи, в яких денотатами виступають числа: трійка; символи, в яких денотатами виступають тварини: змій; символи, в яких денотати-конкретно-історичні особи: Юда Іскаріот, Понтій Пілат, Зосима, Архангел Михайло, Георгій Побідоносець; символи, в яких денотатами $є$ церква та інші релігійні споруди та їх атрибути: хрест, свічка, вівтар, престол, чаша, Царські врата; символи, в яких денотатами виступають вода та сакралізовані продукти харчування: паска, хліб, вино, яйце, писанка (крашанка); символи, де репрезентантами символізованих об'єктів стають ритуали: водне хрещення, хресний хід; символи, де денотатами виступають грошові одиниці: 30 срібняків; символи, де денотатами є рослини (дерева чи їх плоди): верба, яблуко, космічне дерево; символи, де денотатами виступають гори та космічні 
об'єкти: Голгофа, Афон, Віфлеємська зірка; символи, що набувають сакрального семантичного забарвлення виключно в контексті: попіл (як символ покаяння та невідворотності смерті), субота (як символ праведності від діл), дзвін (як символ перемоги, символ вічного буття).

Найбільш частотне використання символів ми спостерігаємо в газеті «Донбасс Православный» (понад 20 найбільш вживаних символів в аналізованих текстах) та журналі «Спасите наши души!». Набагато менше символів міститься в журналі «Живой родник» та газеті «Мир», що зумовлене тим фактом, що матеріали газети «Донбасс Православный» $\epsilon$ автентичними журналістськими працями, а матеріали журналу «Живой родник» найчастіше $\epsilon$ перекладами з інших мов або ж передруками 3 інтернет-сайтів «Православие. Ру», «Седмица. Ру» та російських альманахів. Серед зображальних символів найбільш частотними на шпальтах церковних мас-медіа $є$ хрест, свічка та вівтар.

Аналіз релігійних видань Східної та Центральної України показав, що найбільше релігійних символів концептуалізуються в текстах церковних мас-медіа Східної України та дозволив сконструювати конституційні домінанти та провідні постулати конфесійного стилю, серед яких слід визначити такі: функціонування гетерогенних дискурсів образівсимволів, символічних стилісистем (слів-символів, архетипів та зображальних символів), еклектика публіцистичного та конфесійного, конфесійного та наукового стилів, узус релігійних символів, символів віри та національних українських образів-символів (архетипів), вживання яких обумовлено українським менталітетом та національними звичаями, наявність архаїзмів, церковної термінології (вживання слів для найменування Бога, явищ потойбічного світу, слів на означення відносин людини 3 Богом), гіпертрофія художніх тропів (метафор, епітетів, алегорій та порівнянь, апорій та філософських притч), комунікаційні інтенції 3 підкресленням нумінозності (трактування подій як волі божества) та ієрофанії (вияв священного початку в усіх явищах), інверсія (зворотній порядок слів у реченні для підкреслення урочистості), повтори слів (за допомогою яких робиться акцент на певній думці), стилістично маркована лексика, лексеми із сакральним та переносним значенням, символічні стилістичні звороти (що визначаються амбівалентністю та полісемантичністю), езотеричні доктрини (елементи релігійного вчення, що зрозумілі лише представникам певної конфесіі).

У церковних мас-медіа функціонують символи як з позитивною конотацією (церква, чаша, хрест, вівтар, престол, трійця, світ, вінець, вода, паска), негативною (30 срібняків як символ христопроданства, Голгофа як символ смерті, символ страждань, яблуко як символ 
втраченого раю, символ втраченого неземного блаженства), так i амбівалентною дихотомічною конотацією, що семантизується в контексті (змій як символ мудрості, змій як образ язичництва, змій як символ диявола-спокусника). Особливо значення набувають національні українські символи (архетипи), що характерні для української культури, українського менталітету (символи хліба і вина, що символізують тіло й кров Христову, хліб-сіль, що $є$ символом гостинності в українців). Особливістю конфесійного стилю стає те, що релігійний символ концептуалізується як символ насамперед в контексті («гілки зеленої трави як символ життя», «попіл, який посипається на голови, як символ покаяння та невідворотності смерті», «субота як символ праведності від діл, символ спокою») і стає продукантом символічного ритуалу (ставити свічку в храмі якомусь святому, водне хрещення, хресний хід). Важливим аспектом мови церковних ЗМІ $\epsilon$ функціонування не лише вербальних (лінгвістичних), але й зображальних (екстралінгвістичних) релігійних символів, що сприяють фасилітації декодування реципієнтами мультикультурних релігійних текстів.

Дослідження практичної стилістики релігійної (православної та протестантської) преси Східної та Центральної України дозволило розробити таксонімізацію релігійних символів та визначити в ній 10 провідних груп: символи 3 денотатом числа, тварин, історичних осіб, церкви та релігійних споруд, води та сакралізованих продуктів харчування, ритуалів, грошових одиниць, рослин, гір та космічних об'єктів, контекстуальних символів, які $є$ ідентичними як для православних, так i для протестантських 3MI, і є визначальними концептами дискурсу мови релігійних мас-медіа України.

\section{Література:}

1. Білецька Б. Г. Релігійний символ: сутність та особливості. Вісник Київького національного університету імені Тараса Шевченка. Філософія. Політологія. 2012. Вип. 109. С. 11-14.

2. Ересько М. Н. Язык религии: смысл и символ (опыт онтосемантического анализа): монография. Тюмень: Изд-во Тюменского государственного университета, 2007. 436 с.

3. Кочан Н. Церква - храм як символ неба і землі. Людина і світ. 1994. № 9. С. 42-45.

4. Кочан Н. Церква - храм як символ неба і землі. Людина і світ. 1994. №11-12. C. 43-45.

5. Павлюк Л. С. Знак, символ, міф у масовій комунікації: посібник. Львів: ПАІС, 2006. 120 с. 
6. Сазонова Ю. О. Сучасна релігійна преса Донбасу: стан, функції, перспективи розвитку. Філологічні обрії: збірник наукових пращь молодих учених України. 2011. Вип. 5. С. 160-166.

DOI https://doi.org/10.30525/978-9934-26-039-1-86

\title{
ЗАГОЛОВКОТВОРЕННЯ ЯК ВАЖЛИВА СКЛАДОВА ЖУРНАЛІСТСЬКОГО ТЕКСТУ: ЯК ПОЗБУТИСЯ НЕКЛІКАБЕЛЬНИХ МЕДІАНАЗВ
}

\author{
Шульська Н. М. \\ кандидат філологічних наук, дочент, \\ доцент кафедри сочіальних комунікацій \\ Волинського національного університету імені Лесі Украӥнки \\ м. Луцьк, Україна

\section{Римар Н. Ю.} \\ кандидат філологічних наук, \\ дочент кафедри славістичної філологї, педагогіки \\ та методики викладання \\ Білоцерківського національного аграрного університету \\ м. Біла Церква, Київська область, Україна
}

Зацікавлення інформаційним наповненням будь-якого сучасного масмедіа відбувається передовсім через оригінальну, влучну, логічну палітру заголовкової системи. Відомо, що заголовок - невіддільний конституент журналістського тексту, який виразно «працює» на читача, керує його увагою. Зробити заголовковий комплекс цікавим та інтригуючим, допомогти читачеві зорієнтуватися у порушеній проблемі, точно передати зміст і використати мінімум словесного матеріалу важливе завдання сучасних компетентних 3МI.

У вітчизняних дослідженнях медіаназви проаналізовано у кількох аспектах: 1) розглянуто особливості iï архітектоніки (М. Ріпей [6], В. Шевченко [11- 12]); 2) з'ясовано лексико-семантичні та лексикостилістичні особливості (Н. Шульська [13-14], Г. Шаповалова [10], Л. Солодка [8-9]); 3) описано як засіб впливу на суспільну свідомість (В. Шевченко [11]); 4) представлено проблему способів та засобів увиразнення (Л. Майборода [1-4]); 5) акцентовано увагу на функціях заголовкового комплексу (В. Михайленко [5]) тощо. 